Studia i materiały $\mathrm{z}$ dziedzictwa kulturowego Torunia i regionu,

t. 1: STARE I NOWE DZIEDZICTWO TORUNIA,

Toruń 2013

http://dx.doi.org/10.12775/SiMzDzKTiR_T1.2013.004

Liliana Krantz-Domasłowska

(IZIK UMK, TORUŃ)

\title{
Kościół św. Jakuba w Toruniu - co nowego?
}

Co nowego o kościele św. Jakuba w Toruniu, a dokładniej o jego początkach, etapach realizacji oraz różnorodnych zagadnieniach architektonicznych związanych z tym nietuzinkowym obiektem, napisano w ostatnim okresie? Moja wypowiedź jest rodzajem skróconego stanu badań, próbą wypunktowania nowych ustaleń, propozycji badawczych, bez rozbudowanego komentarza, ale $\mathrm{z}$ intencją poddania ich pod dyskusję. Czy są to hipotezy na tyle przekonywujące, że powinny wejść w obieg powszechnej wiedzy o tym kościele, czy raczej są to idee wymagające dalszej weryfikacji? Należy zauważyć, że część ustaleń opiera się na wynikach badań z dziedzin pokrewnych, jak analiza dendrochronologiczna konstrukcji drewnianych kościoła św. Jakuba ${ }^{1}$, czy eksploracje archeologiczne przy jego wschodniej części ${ }^{2}$ lub wyniki prac konserwatorów³. Są one dla historyka sztuki bardzo cenne, bowiem

1 Aleksander JANKOWSKI, Aleksander KONIECZNY, Izabella BRZOSTOWSKA, Kompleksowa dokumentacja konserwatorska wieży kościoła p.w. św. Jakuba w Toruniu, [mps] Toruń 2002, Archiwum Miejskiego Konserwatora Zabytków w Toruniu, sygn. 2609; Aleksander KONIECZNY, Kompleksowa dokumentacja konserwatorska więźby dachowej prezbiterium kościoła p.w. św. Jakuba Apostoła w Toruniu, [mps] Toruń 2004, Archiwum MKZ w Toruniu, sygn. 2835; Aleksander KONIECZNY, Dokumentacja konserwatorska więźb dachowych korpusu nawowego i kaplicy Ogrójca kościoła p.w. św. Jakuba Apostoła w Toruniu, [mps] Toruń 2006, Archiwum MKZ w Toruniu, sygn. 3584; Aleksander KONIECZNY, Toruń, kościół par. p.w. św. Jakuba Apostoła, kaplica Ogrójca. Ekspertyza dendrochronologiczna,[mps] Toruń 2008, Archiwum MKZ w Toruniu, sygn. 3888; Aleksander KONIECZNY, Toruń, kościół parafialny p.w. św. Jakuba Apostoła w Toruniu, kruchta północna. Ekspertyza dendrochronologiczna, [mps] Toruń 2009, Archiwum MKZ w Toruniu, sygn. 4163; Aleksander KONIECZNY, Toruń, kościół par. p.w. św. Jakuba Apostoła, korpus nawowy. Ekspertyza dendrochronologiczna z dn.30.09.2009, [mps], Archiwum MKZ w Toruniu, sygn.4127.

2 Krystyna SULKOWSKA-TUSZYŃSKA, Toruń - Nowe Miasto 2008. Badania archeologiczno-architektoniczne przy kościele św. Jakuba w Toruniu, [mps] Archiwum Instytutu Archeologii w Toruniu; Anna CICHA, Klasztor cysterek-benedyktynek przy kościele pw. św. Jakuba $w$ Toruniu $w$ świetle źródeł ikonograficznych i archeologicznych,[w:] Dzieje i skarby kościoła Świętojakubskiego w Toruniu, red. K. KLUCZWAJD, Toruń 2010, s. 141-173; KrystynaSUlKOWSKA-TUSZYŃSKA, Anna Cicha, Dawny klasztor przy kościele św. Jakuba w Toruniu i jego otoczenie $w$ świetle badań archeologicznych z lat 2008-2009, „Rocznik Toruński”, t. 37, Toruń 2010, s. 251-273; ponadto artykuł w niniejszym tomie.

3 Gotyckie malowidła ścienne $w$ kościele św. Jakuba $w$ Toruniu. Problematyka badawczo-konserwatorska, red. M. WOŹNIAK, Toruń 2001; Ryszard ŻANKOWSKI, Gotyckie malowidła ścienne w kościele pw. św. Jakuba $w$ Toruniu, odkryte i odrestaurowane w połowie XX wieku. Uwagi konserwatora o ich historii i ponownej, niedawnej konserwacji, [w:] Dzieje i skarby kościoła Świętojakubskiego w Toruniu, red. Katarzyna KLUCZWAJD, Toruń 2010, 
mogą stanowić uzupełnienie badań stylistycznych, czy analiz architektonicznych. Kolejną grupę stanowią wnioski będące teoretyczną reinterpretacją dawnych ustaleń i próbą nowego ujęcia w oparciu o badania historyków ${ }^{4}$, dokładniejsze obserwacje struktury architektonicznej lub szerszą analizą porównawczą ${ }^{5}$. Obie grupy opracowań są cenne i ważne, gdyż poszerzają naszą wiedzę o obiekcie.

Należy jeszcze doprecyzować, co rozumiemy przez określenie „najnowsze badania”. Używam tego zwrotu nie tylko jako kategorii chronologicznej, ale także w sensie poznawczym, roli danego tekstu dla badań nad kościołem św. Jakuba. Taką cezurą, w pierwszym z tych znaczeń, jest synteza Architektura gotycka w Polsce (1995), gdzie w części katalogowej zawarty jest syntetycznie podany przegląd dawnej literatury niemieckiej jak i XX-wiecznych opracowań polskich i niemieckich autorów ${ }^{6}$. Adekwatną pozycją w języku niemieckim jest kompendium Christofera Herrmanna z 2007 roku7 . Natomiast jako przełomową można określić pracę Teresy Mroczko (1980), którą autorka wyznaczyła pewien standard wiedzy o etapach budowy, analogiach formalnych oraz kontekście lokalnej architektury ziemi chełmińskiej, obowiązujący nie tylko w latach osiemdziesiątych XX wieku, ale z którym konfrontują się

s. 175-212; Irena BULDENBERG, Prace konserwatorskie prowadzone na elewacjach kościoła pw. św. Jakuba w Toruniu w latach 2000-2002, 2009, [w:] TAMŻE, s. 161-173.

4 Wspomnieć należy o podstawowych publikacjach: Historii Torunia, red. Mariana BISKUPA, t. 1, Toruń 1999, syntezie Krzysztofa MIKULSKIEGO, Przestrzeń i społeczeństwo Torunia od końca XIV do początku XVIII wieku, Toruń 1999, pracach dotyczących Nowego Miasta Torunia: Antoni CZACHAROWSKI, Początki „Nowych Miast” w państwie krzyżackim, [w:] Czas, przestrzeń, praca w dawnych miastach, red. Andrzej WYROBISZ, Warszawa 1991 s. 47-55; Zenon Hubert NOWAK, Neustadtgründungen des Deutschen Ordens in Preussen. Entstehung, Verhältnis zu den Altstädten, Ende der Eigenständigkeit, [w:] Stadt und Orden. Das Verhältnis des Deutschen Orden zu den Städten In Livland, Preußen und im Deutschen Reich, red. Udo ARNOLD, Marburg 1993, s. 129-142; Marek SŁOŃ, Miasta podwójne $i$ wielokrotne w średniowiecznej Europie, Wrocław 2010; Łukasz MYSZKA, Przywileje odpustowe dla dominikanów toruńskich. Przyczynek do dziejów życia religijnego średniowiecznego miasta, „Nasza Przeszłość”, t. 110, 2008, s. 329-344; Piotr OLIŃSKI, Fundacje mieszczańskie w miastach pruskich w okresie średniowiecza i na progu czasów nowożytnych (Chełmno, Toruń, Elblag, Gdańsk, Królewiec, Braniewo), Toruń 2008; Liliana KRANTZ -DOMASŁOWSKA, Double cities in the Teutonic state on the example of Toruń, RIHA Journal of the International Association of Research Institutes in the History of Art, dostęp online: http://www.riha-journal.org/articles /2013/.

5 Liliana KRANTZ-DOMASŁOWSKA, Zwei Pfarrkirchen und zwei Städte des mittelalterlichen Thorn, [w:] „Beiträge zur Geschichte Westpreußens. Zeitschrift der Copernicus-Vereinigung für zur Pflege der Heimatkunde und Geschichte Westpreußens e.V.“, t. 20/21, Hg. M. GLAUERT, S. KUBON, J. SARNOWSKY, Münster 2006/2008, s. 113-134; Jakub ADAMSKI, Kilka uwag o architekturze kościoła św. Jakuba w Toruniu, „Modus. Prace z historii sztuki", t. 8-9, 2009, s. 5-31; Adam SOĆKO, Trzy etapy budowy chóru kościoła pw. św. Jakuba w Toruniu, [w:] Dzieje i skarby kościoła Świętojakubskiego w Toruniu. Materiały z IV Sesji Naukowej Toruńskiego Oddziału Stowarzyszenia Historyków Sztuki, z cyklu Dzieje i skarby kościołów toruńskich zorganizowanej przy współpracy Biblioteki Uniwersyteckiej UMK w Toruniu, 26-28 października 2009 roku [dalej cyt. DZIEJE I SKARBY 2010], red. K. KLUCZWAJD, Toruń, Toruń 2010, s. 49-71; Jakub ADAMSKI, Pseudopoligonalne sklepienie w chórze kościoła pw. św. Jakuba w Toruniu próba nowego spojrzenia, [w:] TAMŻE, s. 73-90; Aleksander KONIECZNY, Historia budowy kaplic przy kościele pw. św. Jakuba $w$ Toruniu $w$ świetle najnowszych badań architektonicznych i dendrochronologicznych, [w:] TAMŻE, s. 91-120; Jakub ADAMSKI, The Pseudo-poligonal rib vaults St. James' Church in Torun and the question of illusionism in gothic architecture, „Artibus et Historiae”, t. 65 (XXXIII), 2012, s. 275-305; Aleksander KONIECZNY, Dzieje budowy kościoła św. Jakuba w Toruniu w XIV wieku w świetle analizy architektonicznej, „Biuletyn Historii Sztuki”, t. 74, z. 1, 2012, s. 5-32.

6 Teresa MROCZKO, Andrzej WŁODAREK, Kościół parafialny pw. św. Jakuba, [w:] Architektura gotycka w Polsce, red. T. MROCZKO, M. ARSZYŃSKI, t. 2: Katalog zabytków, red. A. WŁODAREK, Warszawa 1995, s. 241-243.

7 Christofer HERRMANN, Mittelalterliche Architektur im Preußenland. Untersuchungen zur Frage der Kunstlandschaft und Geographie, Petersberg 2007, s. 762, 763. 
także współcześni autorzy ${ }^{8}$ Podobną rolę, o czym może świadczyć chociażby liczba cytowań, pełni artykuł Mariana Kutznera z 1986 roku, którego dwa wątki działają na badaczy szczególnie inspirująco ${ }^{9}$. Jeden dotyczy formalnych relacji z chórem kościoła NMP w Lubece (z lat 1251-1270), drugi - szczególnego znaczenia nowomiejskiej fary dla krzyżackiego fundatora, który nadał jej dodatkowe funkcje kościoła zamkowego.

Odrębną jakość prezentują ustalenia Otto Freymutha, którego badania z przełomu lat 40/50. XX wieku opublikowane dopiero w 1981 roku, zostały tylko marginalnie asymilowane przez późniejszych badaczy ${ }^{10}$. Dystans budziły przede wszystkim ustalenia datacyjne, wyznaczające początek prac budowlanych na drugą połowę XIII wieku wobec przyjętej daty (1309 r.) położenia kamienia węgielnego. Wiele obserwacji architektonicznych autora można jednak uznać za godne zastanowienia. W 1998 roku opublikowano niezwykle przydatny dla wszelkich prac rekonstrukcyjnych zbiór rysunków Jerzego Fryderyka Steinera z pierwszej połowy XVIII wieku (Album Steinera $)^{11}$. Na progu nowego tysiąclecia ukazało się opracowanie autorstwa Liliany i Jerzego Domasłowskich o charakterze popularno-naukowym, będące próbą całościowego ujęcia dziejów kościoła św. Jakuba ${ }^{12}$. Przy analizie zagadnień architektonicznych, autorka wyszła od ustaleń Teresy Mroczko i Mariana Kutznera wzbogacając je obserwacjami substancji architektonicznej w skali adekwatnej do wielkości opracowania. Brak przypisów pozbawia tę publikację statusu pracy naukowej, ale jest to dotychczas jedyny tekst o charakterze monograficznym, po którym nastąpiła dłuższa przerwa wydawnicza.

Intensyfikacji badań sprzyjała sesja naukowa poświęcona kościołowi św. Jakuba w 2009 roku $^{13}$. Z zagadnień architektonicznych podjęty został problem zasklepienia części wschodniej kościoła. To jeden z ważniejszych elementów, świadczący o indywidualności pracującego tu architekta. Dwa artykuły - Adama Soćki oraz Jakuba Adamskiego - częściowo się uzupełniają. To zagadnienie poruszył także Aleksander Konieczny w referacie sesyjnym, dotyczącym historii budowy kościoła, którego treść została opublikowana w $2012 \mathrm{r}$. Wymienieni autorzy zwracają uwagę na kluczowe znaczenie zamknięcia wschodniego przę-

8 Teresa MROCZKO, Architektura gotycka na ziemi chełmińskiej, Warszawa 1980, s. 158-168.

9 Marian KUTZNER, Lubecki styl architektury gotyckiej kościoła św. Jakuba w Toruniu, [w:] Sztuka Torunia i Ziemi Chełmińskiej 1233-1815, red. Józef POKLEWSKI, Warszawa - Poznań 1986 („Teka Komisji Historii Sztuki TNT”, t. 7), s. 55-75.

10 Otto FREYMUTH, Untersuchungen zur mittelalterlichen Baugeschichte der Neustädter Pfarrkirche St. Jakobi $z u$ Thorn, [w:] Thorn - Königin der Weichsel 1231-1981, „Beiträge zur Geschichte Westpreußens. Zeitschrift der Copernicus-Vereinigung zur Pflege der Heimatkunde und Geschichte Westpreußens e.V.”, t. 7, Hg. B. JÄHNIG, P. LETKEMANN, Göttingen 1981, s. 13-98. Autor sugeruje, że pierwszy kościół w formie niskiej hali z wielobocznym chórem, krótszym od obecnego oraz wieżą zachodnią, powstał w 2. poł. XIII w. W 1309 r. rozbudowano część wschodnią nadając jej obecny kształt natomiast w latach 40. XIV w. podwyższono nawę główną i korpus uzyskał formę bazylikową.

11 Toruń i miasta ziemi chełmińskiej na rysunkach Jerzego Fryderyka Steinera z 1. połowy XVIII wieku (tzw. Album Steinera), red. M. BISKUP, Toruń 1998.

12 Liliana KRANTZ-DOMASŁOWSKA, Jerzy DOMASŁOWSKI, Kościót świętego Jakuba w Toruniu, Toruń 2001, tu: J. DOMASŁOWSKI, Z historii kościoła; Wyposażenie wnętrza, s. 8-23, 69-137 i L. KRANTZ-DOMASŁOWSKA, Architektura, s. 24-68.

13 DZIEJE I SKARBY 2010. 
sła, tworzącego układ pseudopoligonalny, negują tezę Teresy Mroczko o wtórnej modyfikacji i przedłużeniu chóru o pół przęsła już w trakcie prac oraz akcentują niedostrzeżony wcześniej różny kąt nachylenia pierwszej pary ukośnych przypór w stosunku do narożnych ${ }^{14}$. To ten szczegół jest podstawą dalszego wnioskowania, między innymi - wytyczenia kompozycyjnego punktu zbiegu osi, przechodzących przez ukośne skarpy i glify narożnych okien; punktu, który jest istotny dla wyrysowania zarówno siatki żeber, jak i kształtu oraz podziałów wschodnich przypór i okien. Wszystkie trzy elementy, traktowane całościowo, dają zaplanowany przez projektanta efekt pozornej wieloboczności.

Dalsze wywody Adama Soćki i Jakuba Adamskiego pokazują różne możliwości rekonstrukcji procesu zasklepienia chóru. Atutem opracowania Adama Soćki jest całościowe ujęcie sklepienia chóru uwzględniające także pozostałe przęsła, gdy uwaga Jakuba Adamskiego koncentruje się wyłącznie na wschodnim zamknięciu. Ponadto Soćko prezentując trzy hipotetyczne warianty układu sklepień nie neguje całkowicie starszego pomysłu autorstwa Szczęsnego Skibińskiego o pierwotnym kwadratowym systemie przęseł i sześciodzielnej formie sklepień ${ }^{15}$. Zakłada więc, że koncepcja architekta mogła ewoluować. Obaj autorzy różnie tłumaczą obecność wielobocznej służki na granicy drugiego i trzeciego przęsła, wyróżniającej się wśród pozostałych półokrągłych. Adamski wiąże zmianę formy z wyznaczeniem miejsca na wizerunek patrona, odwołujący się w zredukowanej formie do tradycji przedstawień apostołów we wnętrzach sakralnych ${ }^{16}$. Dla drugiego badacza jest ona argumentem za planowanym na pewnym etapie układem sklepień sześciodzielnych ( za Sz. Skibińskim ${ }^{17}$. Ponadto Aleksander Konieczny dodatkowo tłumaczy różnice w układzie glifów wschodnich otworów okiennych chóru jako wynik projekcji układu okien stosowanych w założeniach poligonalnych na ścianę prostą.

Lektura wymienionych tekstów potwierdza indywidualny charakter rozwiązania toruńskiego sklepienia, pozwala także na kilka pytań. Wschodnie przęsło, gdzie rysunek żeber, kształt wysklepek, podziały ściany z różnej wielkości oknami, ich rozglifieniem (dwudzielne we wschodnim przęśle na ścianach bocznych są także niższe od pozostałych okien trójdzielnych), a także ukośnymi przyporami o różnym stopniu nachylenia należy postrzegać jako przemyślaną, docelową koncepcję architekta, którego nadrzędnym celem było stworzenie unikalnego wrażenia iluzji wielobocznego zamknięcia. Jednak nieregularności w chórze jest więcej, dotyczą one przesunięć służek na międzyokiennych fragmentach muru, tym samym nie „trafiają” one w osie wyznaczone przez rytm przypór (mowa o pozostałych przęsłach chóru). Czy to tylko dopuszczalny błąd w sztuce, a może architekt zaczął swój projekt zasklepienia chóru od pomysłu na swoisty układ wschodniego przęsła i to struktura żeber i służek wyznacza regularną osnowę nałożoną na boczne ściany, których podziały okienne i przypory wyznaczają nieco inny rytm? Może jednak przyczyna jest bardziej prozaiczna. Idąc tro-

14 MROCZKO 1980, s. 167; SOĆKO 2010, s. 54; ADAMSKI 2009, s. 17; ADAMSKI 2010, s. 76; KONIECZNY 2012, s. $8-12$.

15 Szczęsny SKIBIŃSKI, Kaplica na Zamku Wysokim w Malborku, Poznań 1982, s. 63.

16 ADAMSKI 2009, s. 23.

17 SOĆKO 2010, s. 63, 64. 
pem Otto Freymutha, który zakładał istnienie wcześniejszego wielobocznego chóru, to jego kształt wymusił niektóre rozwiązania obecnego prezbiterium. Pośrednim dowodem może być rysunek Ireneusza Sławińskiego z 1942 roku, prezentujący odkryte wtedy pozostałości wielobocznego zamknięcia w wykopie wykonanym na zlecenie Freymutha, który przytaczam za Eugeniuszem Gąsiorowskim ${ }^{18}$. Nowych argumentów mogą dostarczyć badania archeologiczne od 2008 roku prowadzone przez Krystynę Sulkowską-Tuszyńską i Instytut Archeologii UMK.

Otwarta pozostaje kwestia datowania sklepienia chóru, czy wykonano je w ramach prac przy wschodniej części, czy wraz ze sklepieniem korpusu, jak sugerowała Teresa Mroczko, a jeszcze wcześniej Jerzy Frycz? ${ }^{19}$ Przywoływani poprzednio autorzy widzą założenie sklepień jako etap wieńczący prace przy wschodniej części kościoła, Adam Soćko wskazuje, że ostateczna koncepcja powstała około 1320 roku, a zrealizowano ją w trzeciej dekadzie XIV wieku, natomiast Aleksander Konieczny i Jakub Adamski wyznaczają datę ukończenia chóru wraz ze sklepieniami w oparciu o badania dendrochronologiczne na 1320 rok $^{20}$.

W tekstach z lat 2009, 2010 oraz 2012, Jakub Adamski podjął również wątek genezy sklepień pseudopoligonalnych, prezentując szeroki materiał porównawczy i dowodząc, że przykład toruński - choć indywidualny, świadczący o wyobraźni przestrzennej architekta przynależy do licznej grupy obiektów z terenu środkowej Europy. Ten sam typ sklepień pojawił się we Francji już na przełomie XII i XIII wieku, zyskując później popularność szczególnie na terenie Niemiec. Niezależnie od obiektów, które przywoływane były jako ważne w starszej literaturze - jak kościół św. Jakuba w Rostocku (T. Mroczko) lub kaplica zamku w Lochstedt (Sz. Skibiński) - autor zwraca uwagę na znaczącą rolę chóru katedry w Hamburgu (1251-1255) i jego pochodne, akcentując jednocześnie, że dla toruńskiego twórcy charakterystyczna była wielość inspiracji ${ }^{21}$. Przytoczone tu nowe propozycje badawcze dotyczące części chórowej kościoła św. Jakuba koncentrują się głównie na rekonstrukcji kształtu wschodniego przęsła oraz pseudopoligonalnego układu sklepień, cech nadających nowomiejskiej farze rys indywidualności.

Przedmiotem zainteresowania był także korpus nawowy. Dwa teksty Aleksandra Koniecznego stanowią propozycję nowego ujęcia faz budowy oraz rekonstrukcji jego układu 22 . Prace przy kościele św. Jakuba były dotychczas przez badaczy dość zgodnie postrzegane

18 Eugeniusz GĄSIOROWSKI, Zaginione średniowieczne kościoły Torunia, „Archeologia Historica Polona”, t. 19, 2011, s. 71-103, rys. s. 85; FREYMUTH 1981, s. 64-68.

19 MROCZKO 1980, s. 167, 168. Autorka optowała za jednoczesnym przesklepieniem korpusu i chóru wskazując na jednakowy przekrój żeber w obu częściach kościoła i datując na około 1340 r. rozumiany jako końcowy etap prac przy nowomiejskiej świątyni; Jerzy FRYCZ, Architektura zamków krzyżackich, [w:] Sztuka pobrzeża Bałtyku. Materiały Sesji SHS, Gdańsk, listopad 1976, red. H. FRUBA, Warszawa 1978, s. 46.

20 SOĆKO 2010, s. 71; ADAMSKI 2010, s. 74; KONIECZNY 2012, s. 11-14. Autor wskazuje dodatkowo na kompletność więźby dachowej w części wschodniej.

21 ADAMSKI 2009, s. 17; ADAMSKI 2010, s. 81-88; Jakub ADAMSKI, Sklepienia pseudopoligonalne w architekturze gotyckiej. Studium z dziejów architektonicznego iluzjonizmu (w druku).

22 Aleksander KONIECZNY, Historia budowy kaplic przy kościele pw. św. Jakuba w Toruniu w świetle najnowszych badań architektonicznych $i$ dendrochronologicznych, [w:] DZIEJE I SKARBY 2010, s. 91-120 oraz wspomniany już tekst referatu z 2009 r., opublikowany w 2012 r. 
jako przebiegające w sposób ciągły, ujmowane w ramy czasowe 1304/9-1340/50, w które wpisywały się poszczególne części: chór do 1320 roku, korpus do 1340 roku, wieża do $1350 \mathrm{roku}^{23}$ Autor, opierając się na obserwacjach substancji architektonicznej oraz wynikach badań dendrochronologicznych zachowanych konstrukcji drewnianych, proponuje nową periodyzację. Uwzględniany w literaturze fakt samodzielnego funkcjonowania ukończonej części wschodniej w okresie, gdy realizowany był korpus (T. Mroczko, L. Krantz-Domasłowska), dla Aleksandra Koniecznego oznacza dłuższą cezurę, przyjmuje bowiem, że prace podjęte mogły być nawet po dwudziestu latach ${ }^{24}$. Nowe odczytanie śladów i nieregularności pozwoliło Autorowi doprecyzować kolejność wznoszonych części korpusu. Miały powstawać kolejno: ściany obwodowe korpusu i filary wieży; podpory i arkady międzynawowe; 2 . kondygnacja wieży i dachy pulpitowe nad aneksami przywieżowymi; więźby nad nawami bocznymi; ściany nawy głównej i łuki odporowe; więźba nawy głównej i sklepienia oraz podwyższona kondygnacja wieży, jej zwieńczenie zniszczone podczas pożaru Nowego Miasta w 1455 roku odnowione zostało po kilkunastu latach ${ }^{25}$. Ważne uzupełnienie stanowi propozycja uściślenia faz budowy korpusu w oparciu o badania dendrochronologiczne ${ }^{26}$. Zamykają je dwie daty, przed 1359 rokiem - druga kondygnacja wieży i aneksów bocznych oraz po 1361 roku - trzecia kondygnacja wieży. Pomiędzy nimi mieszczą się pozostałe górne partie korpusu.

O ile logika prowadzonych kolejno prac nie budzi zastrzeżeń, to proponowana długa przerwa między ukończonym już chórem, a realizacją korpusu zastanawia i skłania do pytania o przyczynę. Zwraca uwagę kilka faktów. Kumulacja funkcji liturgicznych w części wschodniej, tych podstawowych związanych z cura animarum dla mieszkańców Nowego Miasta, musiała trwać przez okres blisko czterdziestu lat oraz klasztornych (jeżeli przyjmiemy opcję fizycznej obecności zakonnic po przekazaniu im patronatu nad kościołem św. Jakuba) - przez około dwadzieścia lat. Jeżeli udział cysterek-benedyktynek uznamy tylko za formalno prawny przywilej, to decyzja o pozostawieniu chóru w formie właściwie skończonej i to tak elitarnej przez tak długi czas przez krzyżackiego fundatora, wydaje się niezrozumiała. Kontrargumentów dostarcza także materia architektoniczna - wykorzystanie glazurowanych literowych plakietek w portalu zachodnim, będących pozostałością po bogatej

23 Rok 1304 podany jest w aktach wizytacyjnych z XVIII w. jako czas utworzenia parafii w Nowym Mieście Toruniu, za: Waldemar ROZYNKOWSKI, Powstanie i rozwój sieci parafialnej $w$ diecezji chełmińskiej w czasach panowania zakonu krzyżackiego, „Roczniki Towarzystwa Naukowego w Toruniu”, t. 89, z. 2, 2000, s. 80. Rok 1309 został utrwalony w inskrypcji okalającej wnętrze prezbiterium w kontekście położenia kamienia węgielnego przez biskupa chełmińskiego Hermana. Natomiast 1340/45 r., kończący zasadnicze prace budowlane, przywoływany jest w oparciu o dokument wielkiego mistrza Ludolfa Königa, w którym potwierdził on nadanie kościoła zakonowi żeńskiemu przez swego poprzednika Dietricha von Altenburg (1335-1341), zob. Urkundenbuch des Bisthums Culm, Hg. Carl P. WOELKY, Danzig 1885-1887, cz. 1, 281, s. 211. Ponadto Architektura gotycka w Polsce, red. T. MROCZKO, M. ARSZYŃSKI, t. 2: Katalog zabytków, red. A. WŁODAREK, Warszawa 1995, s. 241-243.

24 KONIECZNY 2012, s. 20. Autor zakłada, że inicjatywa kontynuowania prac przy korpusie mogłaby wiązać się z przejęciem kościoła przez benedyktynki.

25 TAMŻE, s. 29. Obecny dach wieży założono w 1467 r., a konstrukcję dzwonną w 1470 r. Ponadto ilustracje $\mathrm{nr} 32,33,34,35,40,42,43,44$ prezentują poszczególne fazy budowy korpusu w formie rysunkowych rekonstrukcji.

26 TAMŻE, il. 45, s. 27, 28, przypis 20, 25. Ponadto badania więźby nad nawą główną świadczą o ścince drzew w okresie jesienno-zimowym 1360/1361, a w konsekwencji jej budowie najwcześniej w 1361r. KONIECZNY 2009. 
ceramicznej dekoracji chóru, może świadczyć o niezbyt odległym dystansie czasowym między wschodnią i zachodnią częścią kościoła (co nie wyklucza innego, mniej biegłego wykonawcy tego fragmentu budowli). Dokładniejszych analiz wymaga także podobieństwo formy żeber sklepiennych chóru i korpusu, które miałby dzielić okres ponad czterdziestu lat.

Aleksander Konieczny znalazł nowe uzasadnienie opinii, że korpus stanowił realizację odrębnego projektu architektonicznego - nie powiązanego czasowo, stylistycznie i warsztatowo z chórem. W dotychczasowych badaniach różnice formalne między obu częściami postrzegano nie tylko jako efekt pracy innych ekip wykonawczych, ale też świadomy wybór różnych modusów stylowych, odpowiadających odrębnym funkcjom poszczególnych części kościoła. Autor, rozczytując na nowo zachowane ślady i częściowo reinterpretując obserwacje Freymutha, rekonstruuje pierwotnie planowany wraz z chórem korpus jako układ pseudobazylikowy ${ }^{27}$. Zmiana konceptu na układ bazylikowy miałaby nastąpić spontanicznie w trakcie prac, gdy zdecydowano o podwyższeniu o około 1,6 m ściany międzynawowej (według Koniecznego odpowiada to fazie realizacyjnej z lat 50. XIV wieku). Owa spontaniczność miała dalsze konsekwencje: oznaczała nie tylko wprowadzenie strefy okiennej, ale wymusiła uwarunkowane względami konstrukcyjnymi, zastosowanie łuków odporowych. Logiczny i przekonywujący wywód Aleksandra Koniecznego dowodzi istnienia pierwszego pseudobazylikowego projektu korpusu, który faktycznie nigdy nie został zrealizowany. Natomiast wydaje się, że zmiana konceptu musiała nastąpić wcześniej niż w latach 50. XIV wieku, już w trakcie realizacji ścian obwodowych korpusu, bowiem - jak sugeruje Autor - zrealizowano je w pierwszej fazie i jako niższe od pierwotnie planowanych ${ }^{28}$. Pięciodzielne służki wiązkowe, będące elementem członującym filary międzynawowe oraz obecne jako podstawowy element wertykalny ściany międzynawowej, także przynależą do pierwszej fazy realizacyjnej korpusu, ponieważ chronologicznie wcześniej pojawiły się na ścianie lateralnej.

Czy obecność ganku oraz systemu nisz, które miały również znaczenie konstrukcyjne, należy łączyć z projektem, który był realizowany od początku podjęcia prac przy korpusie, pozostanie kwestią otwartą. Podobnie nieweryfikowalne jest ustalenie, czy strefa okien jest pomysłem wtórnym. Ślady zinterpretowane przez Koniecznego jako pierwszy pseudobazylikowy korpus nie dostarczają żadnej wiedzy o systemie artykulacji ściany międzynawowej, pozwalają jedynie określić jej nieco inną wysokość. Natomiast ślady na drugiej kondygnacji wieży, sugerujące chęć postawienia niższej nawy głównej, są nie tylko argumentem za trwaniem pierwotnej koncepcji korpusu, ale także za możliwością kolejnego wariantu relacji między nawami ${ }^{29}$. Brak wielu danych skłania do analizy tego, co zostało ostatecznie zrealizo-

27 TAMŻE, s. 14, 15, 21, 22. Autor wskazuje m.in. na niedowiązane górne fragmenty ścian międzynawowych oraz ślad na ścianie tęczowej jako opór planowanego sklepienia nawy głównej (ten sam element Mroczko interpretuje jako pozostałość po zmianie wykroju łuku tęczowego, MROCZKO 1980, s. 167), jako dowody świadczące o planowanej niższej nawie głównej. Na podstawie analizy architektonicznej wschodnich ścian naw bocznych, które zostały częściowo zrealizowane podczas budowy prezbiterium, wnioskuje on dalej, że pierwotnie nawy boczne miały być znacznie wyższe. Konsekwencją małej różnicy wysokości było ograniczenie możliwości wprowadzenia strefy okiennej w nawie głównej.

28 KONIECZNY 2012, s. 21, il. 32.

29 TAMŻE, s. 22. Jest to brak przewiązania górnych warstw ścian międzynawowych z wieżą, obecność śladów pierwotnego otworu wejściowego $\mathrm{z}$ wieży na poddasze nawy. 
wane, a tą formą jest układ bazylikowy, być może będący efektem modyfikacji, której dokonano już na początku przystępując do budowy ścian lateralnych oraz filarów międzynawowych. Podobnie wprowadzenie łuków odporowych, określonych przez Koniecznego za Freymuthem jako „arachityczne” z pewnością było rodzajem konstrukcyjnego zabezpieczenia, ale dzięki temu w jednym wnętrzu spotkały się dwa sposoby budowania statyki - wywodzący się z romańskiej tradycji grubego muru oraz gotycki system wzmocnień łukami odporowymi ${ }^{30}$. Oba zadecydowały także o formalno stylistycznej specyfice korpusu kościoła św. Jakuba. Wizualną wartość nie spotykanego na terenie państwa krzyżackiego rozwiązania poświadcza decyzja z 1861 roku, gdy zbudowano nową więźbę nad nawą i kaplicami północnymi ${ }^{31}$. Wtedy też zdecydowano o odsłonięciu łuków odporowych oraz zaprezentowaniu pierwotnej wielkości okien nawy głównej. Wzniesiono połać dachu o niewielkim spadku przykrywającą północną część korpusu (kaplice i nawę boczną). Zdjęcie z 1908 roku rejestruje ten wygląd. ${ }^{32} \mathrm{~W}$ kolejnych latach nastąpiła zmiana, podwyższono dach, który ponownie przykrył elementy dawnej gotyckiej konstrukcji.

Hipotezy Aleksandra Koniecznego wymagają szczegółowej refleksji. Ich przyjęcie w wersji podstawowych ustaleń dotyczących zmiany chronologii (przystąpienie do prac nad korpusem po długiej przerwie i wydłużenie czasu budowy do lat 60. XIV wieku) oraz wtórności koncepcji bazylikowego układu korpusu zmienia optykę całej budowli. Aktualności nabierają stare pytania o genezę form, kontekst historyczny oraz relacje z pozostałymi kościołami Torunia.

Z ostatnim tekstem Aleksandra Koniecznego koresponduje jego nieco wcześniejszy artykuł z 2010 roku, opublikowany w materiałach posesyjnych, dotyczący dobudowanych do korpusu kościoła św. Jakuba kaplic bocznych, gdzie autor zaprezentował całkowicie nową kolejność ich powstawania i lokalizacji. Opierając swoją opinię na obserwacji lica półszczytów zamykających poszczególne wnętrza, a widocznych na kondygnacji strychów, zasugerował, że szereg południowy powstawał w kierunku odwrotnym niż przyjmował J. Heise, a za nim pozostali badacze, czyli od zachodu ku wschodowi, natomiast kierunek dobudowy północnych aneksów prowadził od wschodu ku zachodowi ${ }^{33}$. Obserwacje te dowodzą, że proces dobudowy kaplic przebiegał stopniowo, odpowiadając kolejnym fundacjom. Dla uściślenia bezwzględnego datowania kaplic Autor przywołuje sugestie Heisego przyjmując, że prace podjęto około 1425 roku i realizowano szybko ${ }^{34}$. Wnioski Autora należałoby skon-

30 KRANTZ-DOMASŁOWSKA, DOMASŁOWSKI 2001, s. 59.

31 KONIECZNY 2006, s. 12.

32 Zdjęcie z 1908 roku autorstwa Alexandra Jacobi znajduje się w zbiorach Książnicy Toruńskiej. Serdecznie dziękuję za udostępnienie powyższego materiału.

33 KONIECZNY 2010, s. 91-120. W szeregu południowych aneksów brak jednoznacznego argumentu na rzecz chronologicznego pierwszeństwa południowo-zachodniej kaplicy (obecnie św. Krzyża) nad południowo-wschodnią (obecnie Matki Bożej Bolesnej), obie bowiem funkcjonowały przez pewien czas samodzielnie. Natomiast malowana dekoracja pasowa na wschodnim półszczycie kolejnej kaplicy (obecnie św. Anny) mogła nawiązywać do malarskiego opracowania półszczytu stojącej już kaplicy Matki Bożej Bolesnej.

34 Johannes HEISE, Die Bau- und Kunstdenkäler der Provinz Westpreußen, Bd. 2, Kulmerland und Löbau, H. 7, Der Kreis Thorn. Die Stadt Thorn, Danzig 1889, s. 301. Heise oparł swoją propozycję datowania na stylistycznym podobieństwie z realizowanymi na początku XV w. kaplicami fary Starego Miasta Torunia. 
frontować z ustaleniami Piotra Olińskiego, dla którego źródłem jest nie materia architektoniczna, a tekst źródłowy ${ }^{35}$. Relatywnie późne, najczęściej piętnastowieczne wzmianki dotyczące fundacji, wikariatów, wezwań - nie wykluczają wcześniejszego funkcjonowania kaplicowych aneksów. Jednak najbardziej kontrowersyjną wydaje się propozycja Koniecznego, dotycząca nowej lokalizacji kaplicy rodziny Jungeweise, jedynej poświadczonej źródłowo wczesnej fundacji (1359 r.), którą dotychczas utożsamiano z południowo wschodnim aneksem korpusu ${ }^{36}$. Autor zaproponował miejsce, odpowiadające jego koncepcji wydłużonej chronologii budowy korpusu - przestrzeń w północnym aneksie przywieżowym, pełniącym obecnie funkcję wewnętrznej kruchty lub alternatywnie w znajdującym się powyżej pomieszczeniu, określanym aktualnie jako archiwum/skarbiec. Czy jednak realizowany projekt części zachodniej kościoła zakładał taką właśnie funkcję północnego aneksu przywieżowego, czy raczej byłaby to wtórna lokalizacja adaptująca przestrzenie, które pierwotnie miały mieć inne przeznaczenie?

Jednym z ważniejszych zagadnień architektonicznych nowomiejskiej fary jest geneza form. Problematykę tę najpełniej przedstawili Teresa Mroczko i Marian Kutzner. Wątek inspiracji i źródeł zawierają też wspomniane już teksty Jakuba Adamskiego, w których autor dyskutuje z opinią Mariana Kutznera o lubeckim rodowodzie korpusu nawowego. Archaizujący plan o reminiscencjach systemu wiązanego kojarzy z lokalną architekturą ziemi chełmińskiej (kościół Franciszkanów pw. św. Jakuba w Chełmnie), natomiast postromański sposób artykulacji ściany międzynawowej postrzega jako twórczo przerobiony motyw o lubeckiej genezie, spotykany także w innych farach miast hanzeatyckich ${ }^{37}$. Nie uwzględnia natomiast w swej analizie strony zewnętrznej, przykładowo obecności łuków odporowych, zmieniających optykę z elementów archaizujących lub postromańkich na jak najbardziej współczesne. Problem genezy form podejmują również autorki średniowiecznej części Dziejów Sztuki Torunia, Anna Błażejewska i Elżbieta Pilecka, wskazując na istotną rolę transformacji gotyckich form kamiennych, wywodzących się z Górnej Nadrenii i Szwabii na materię ceglaną, jako wyraz „arystokratyzacji” budowli, tutaj wpisujący się w specyficzną rolę nowomiejskiej fary - kościoła ściśle związanego z krzyżackim fundatorem ${ }^{38}$.

Ostatnie słowa ukierunkowują na niezwykle nośny, poruszany w starszej literaturze jak i najnowszych opracowaniach temat fundacji i wpływu inwestora na kształt nowej budowli parafialnej. Wysublimowana forma kościoła św. Jakuba w sposób szczególny sprzyja tym dywagacjom. Odrębny artykuł poruszający to zagadnienie zwalnia od szczegółowej anali$\mathrm{zy}^{39}$. Warto nadmienić, że zarysowujący się już u dziewiętnastowiecznych autorów dualizm poglądów znalazł swoich współczesnych kontynuatorów w osobach Mariana Arszyńskiego - zwolennika ograniczonego wpływu krzyżaków na budowę i kształt kościoła św. Jakuba

35 OLIŃSKI 2008, s. 207-222.

36 KONIECZNY 2010, s. 119.

37 ADAMSKI 2009, s. 7-15.

38 Anna BŁAŻEJEWSKA, Elżbieta PILECKA, Sztuka średniowieczna, [w:] Anna BŁAŻEJEWSKA, Katarzyna KLUCZWAJD, Bogusław MANSFELD, Elżbieta PILECKA, Jacek TYLICKI, Dzieje sztuki Torunia, Toruń 2009, s. 68.

39 Zob. artykuł A. Błażejewskiej w niniejszym tomie. 
oraz Christofera Herrmanna - prezentującego w tej materii skrajnie purystyczne promieszczańskie stanowisko ${ }^{40}$. Natomiast Marian Kutzner należy do zwolenników ścisłych związków finansowych i organizacyjnych z Zakonem, wynikających z szeroko rozumianego prawa patronatu i w konsekwencji także - ich wpływu na kształt budowli4 ${ }^{41}$. Nową, pośrednią opcję zaproponował Aleksander Konieczny wskazując, że chór jest fundacją krzyżacką, a korpus - nowomiejskich mieszkańców ${ }^{42}$.

Poruszone tu kwestie nie wyczerpują całego spektrum zagadnień, związanych z nowomiejską farą, są wyborem starszych i nowych hipotez badawczych, które przybliżają prawdę o obiekcie, pozostawiając nas w przekonaniu, że kościół św. Jakuba nadal jest dziełem otwartym.

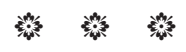

\section{What's New in St. James' Church?}

The text features new research opportunities regarding the initiation of the construction, its stages and various other architectural issues connected with the St. James' church in Torun that have been issued in recent years. The most fundamental question was whether these hypotheses are convincing enough to become a part of common knowledge about this church or maybe require further verification. A part of new ascertainment bases upon the findings in related sciences, such as the dendrochronological analysis of the roof, archaeological explorations or restoring (footnote 1, 2, 3). The second group consists of conclusions concerning the theoretical reinterpretation of former findings and bases on closer inspection of architectural structure or broader comparative research (footnote 5). In many cases it is a discussion or development of the theses included in the works of Marian Kutzner and Teresa Mroczko, that established certain long-lasting standard of knowledge about the parish church of New Town Torun. I shall also mention the new research opportunities focused on two major issues, the shape reconstruction of the east bay and the pseudopolygonal vaulting pattern, so much as the chronology of works by the nave with the reconstruction of its initial shape.

The eastern part of the church is unanimously regarded as an individual creation of the architect working herein. The articles both by Jakub Adamski (2009, 2010, 2012) and Adam Soćko (2010) state, that the idea of creating an illusion of polygon in the eastmost bay with all

40 Marian ARSZYŃSKI, Stosunki między zakonem krzyżackim a społeczeństwem $w$ świetle rozważań nad organizacją budowy kościołów parafialnych w Prusach, [w:] Zakon krzyżacki a społeczeństwo państwa w Prusach, red. Z. H. NOWAK, („Rocznik Towarzystwa Naukowego w Toruniu”, t. 86), Toruń 1995, s. 165-184; HERRMANN 2007, s. 273; Christofer HERRMANN, Kościoły krzyżackie (Ordenskirchen) - fakt czy mit? O relacjach między patronatem i mecenatem w średniowiecznych Prusach, „Studia Zamkowe”, t. 4, Malbork 2012, s. 67-76.

41 Marian KUTZNER, Der Lübische Stil und die Jakobskirche in Thorn, [w:] Mittelalterliche Backsteinarchitektur und bildende Kunst im Ostseeraum, Greifswald 1987, s. 32; KRANTZ-DOMASŁOWSKA, DOMASŁOWSKI 2001, s. 63-65.

42 KONIECZNY 2012, s. 30. 
elements creating this effect should be regarded as the execution of architect's original plan. As a new argument both authors indicate a new detail - the angle alignment differentiation in the eastern pair of buttresses. These observations shall be regarded valid as long as new archaeological exploration is conducted. Moreover, J. Adamski takes up the problem of the origin of pseudopolygonal vaulting indicating the importance of the Hamburg Cathedral's choir, at the same time pointing out that the architect of St Jacob's is characterized by multitude of inspirations.

Two texts of Aleksander Konieczny $(2010,2012)$ concern the new findings on the nave (footnote 22). The author verifies previous opinions confirming that the works by the St James' church had been conducted continuously in two phases (1309-1320, the choir and 1320-1344/50, the nave and the tower). Basing upon the results of the roof dendrochronological analysis, he proposes a 20 year interruption and the finalization of the western part before 1359 (upper storeys of the tower in 1361), side aisles - 1359, nave - 1361. This long break raises certain amount of doubt, for its consequences would imply a accumulation of liturgical functions in the completed eastern part connected with cura animae for the inhabitants of the New Town for the period of ca. 40 years, so much as monastic functions for ca. 20 years if we accept the real presence of the Benedictine nuns, after the patronage have been handed over to them. The result of the changes in dating and interpretation of architectural evidence is an opinion that the existing form of a basilica is secondary, for the primary project was to build a pseudobasilica. Implementing a new, but never achieved architectural idea changes the view on the entire structure and regardless of the fact that Konieczny's line of reasoning is quite convincing, it lacks an explicit proof describing what was the primary plan for inner wall division. The new Konieczny's findings also concern the sequence of side chapels construction by the aisles, while the most controversial proposition is to locate the oldest, confirmed by the historical records, the foundation of the Jungeweise family in the annex by the northern tower. 


\section{SPIS ILUSTRACJI:}

1. Toruń, kościół św. Jakuba, bryła widok od pn-wsch., fot. Andrzej Skowroński.

2. Toruń, kościół św. Jakuba, rzut wg Teresy MROCZKO, L. KRANTZ-DOMASŁOWSKA, J. DOMASŁOWSKI, Kościół św. Jakuba w Toruniu, Toruń 2001, s. 27.

3. Toruń, kościół św. Jakuba, możliwe warianty zasklepienia chóru wg rekonstrukcji A. Soćki (A, B); wg Sz. Skibińskiego (D); zrealizowany układ sklepień (C), A. Soćko, Trzy etapy budowy chóru kościoła pw. św. Jakuba, [w:] Dzieje i skarby kościoła Świętojakubskiego w Toruniu, Toruń 2010, il. s. 50 .

4. Toruń, kościół św. Jakuba, rysunek wschodniego przęsła chóru z zaznaczonym rysunkiem żeber i osiami kompozycyjnymi wg J. Adamskiego, J. Adamski, Pseudopoligonalne sklepienie w chórze kościoła pw. św. Jakuba w Toruniu, [w:] Dzieje i skarby kościoła Świętojakubskiego w Toruniu, Toruń 2010, il. 4, s. 78.

5. Toruń, kościół św. Jakuba, fragment północnej ściany chóru, fot. A. Skowroński.

6. Rysunek I. Sławińskiego z 1942 r. prezentujący ukośny układ wschodnich przypór chóru zaobserwowany w wykopie wykonanym na zlecenie O. Freymutha, wł. E. Gąsiorowski, E. Gasiorowski, Zaginione średniowieczne kościoły Torunia, „Archeologia Historica Polona”, t. 19, Toruń 2011, il. 13 , s. 85 .

7. Toruń, kościół św. Jakuba, wnętrze, fot. A. Skowroński.

8. Toruń, kościół św. Jakuba, datowanie poszczególnych faz budowy korpusu i wież w oparciu o wyniki badań dendrochronologicznych, wg. A. Koniecznego, A. Konieczny, Dzieje budowy kościoła św. Jakuba w Toruniu w XIV wieku, „Biuletyn Historii Sztuki”, 1/2012, il. 45, s. 27.

9. Toruń, korpus kościół św. Jakuba, ściana północna, fot. A. Skowroński.

10. Toruń, elewacja północna korpusu kościoła św. Jakuba, zdjęcie Alexandra Jakobi z 1908 roku, zbiory Książnicy Toruńskiej. 


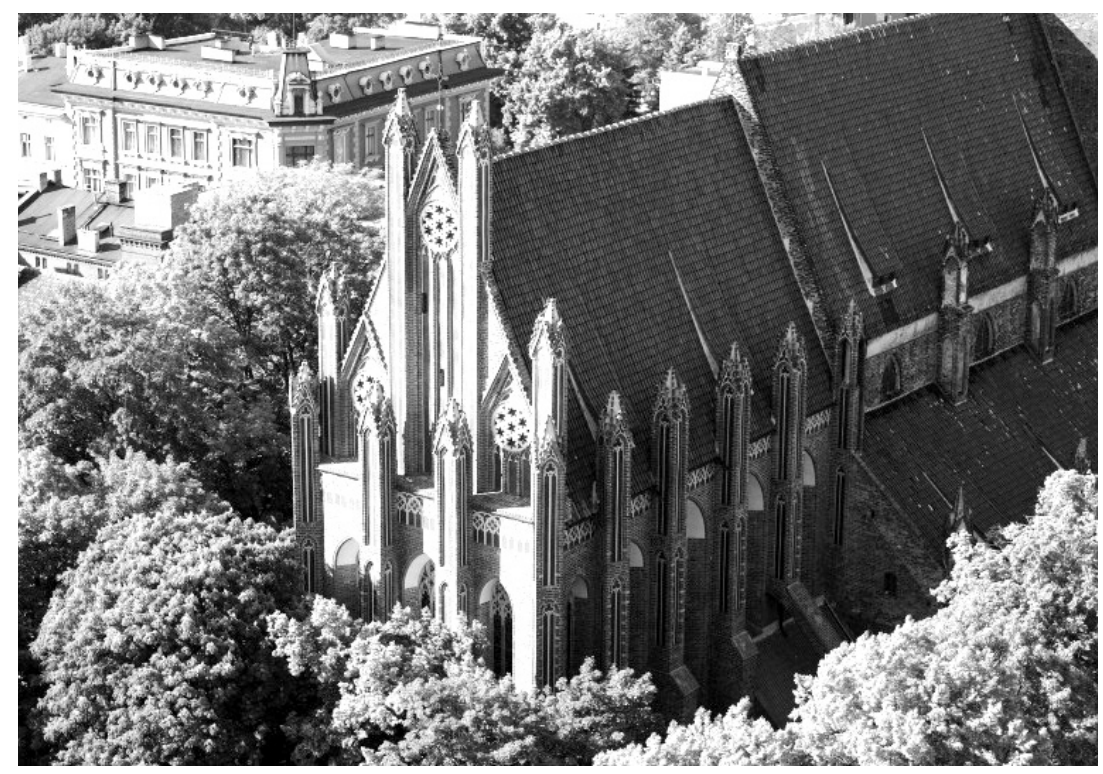

Il. 1 Toruń, kościół św. Jakuba, bryła widok od pn-wsch., fot. Andrzej Skowroński

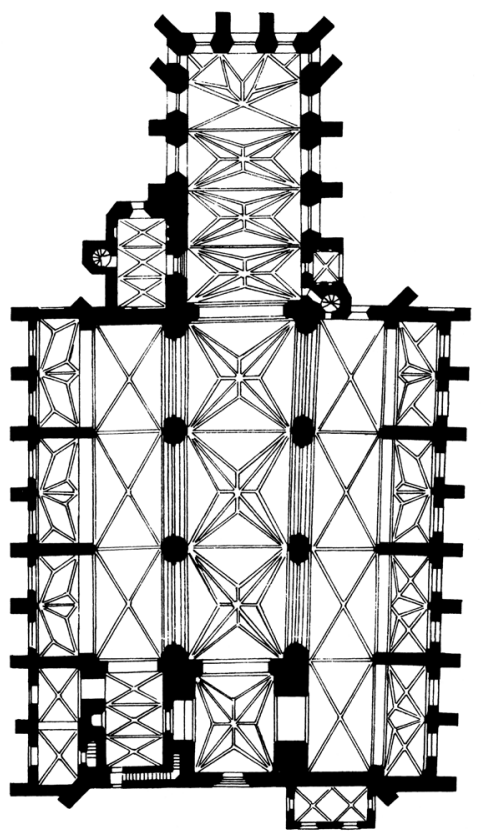

Il. 2 Toruń, kościół św. Jakuba, rzut wg Teresy Mroczko, L. Krantz-Domasłowska, J. Domasłowski, Kościół św. Jakuba w Toruniu, Toruń 2001, s. 27 


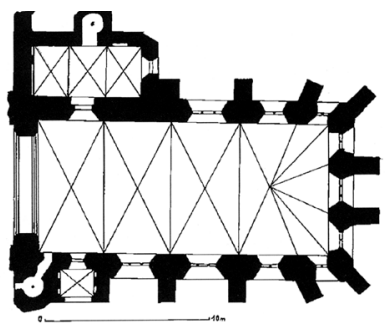

A

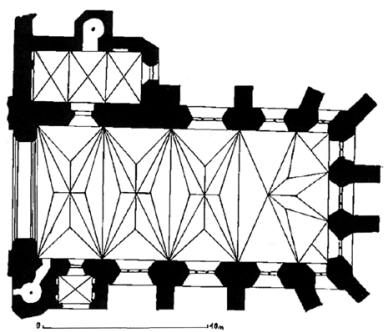

C

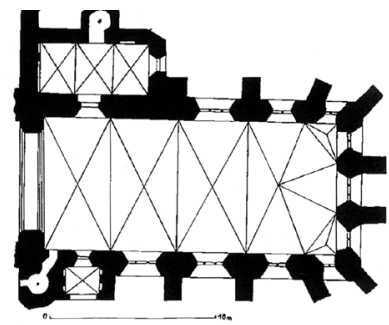

B

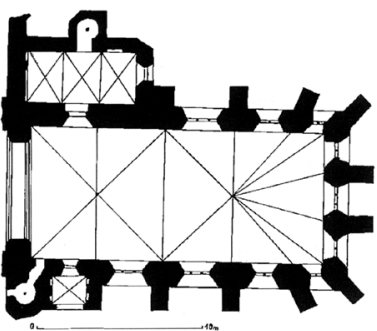

D

Il. 3 Toruń, kościół św. Jakuba, możliwe warianty zasklepienia chóru wg rekonstrukcjiA. Soćki (A, B); wg Sz. Skibińskiego (D); zrealizowany układ sklepień (C), A. Soćko, Trzy etapy budowy chóru kościoła pw. św. Jakuba, [w:] Dzieje i skarby kościoła Świętojakubskiego w Toruniu, Toruń 2010, il. s. 50

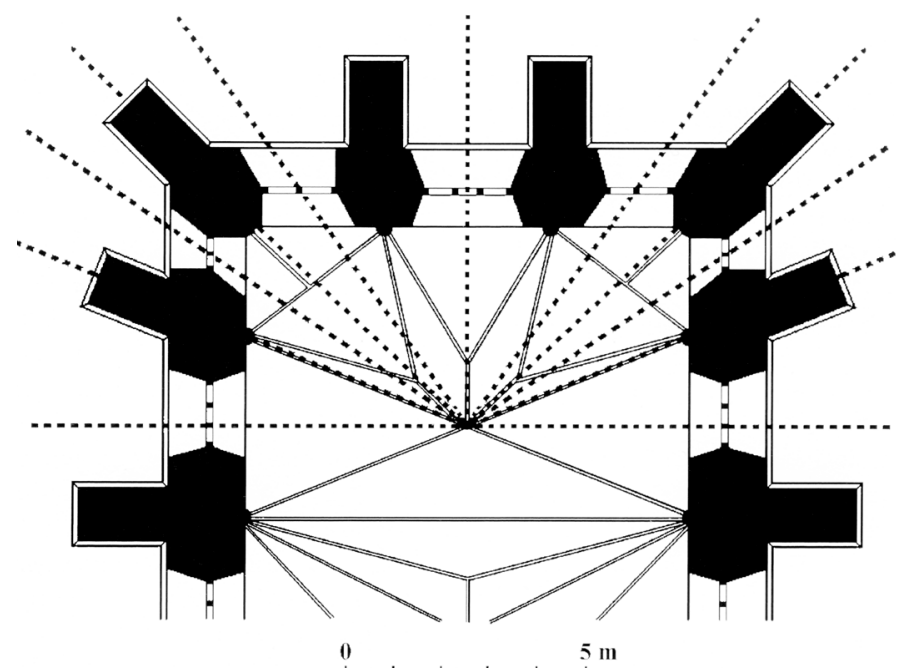

Il. 4 Toruń, kościół św. Jakuba, rysunek wschodniego przęsła chóru z zaznaczonym rysunkiem żeber i osiami kompozycyjnymi wg J. Adamskiego, J. Adamski, Pseudopoligonalne sklepienie $w$ chórze kościoła pw. św. Jakuba w Toruniu, [w:] Dzieje i skarby kościoła Świętojakubskiego w Toruniu, Toruń 2010, il. 4, s. 78 


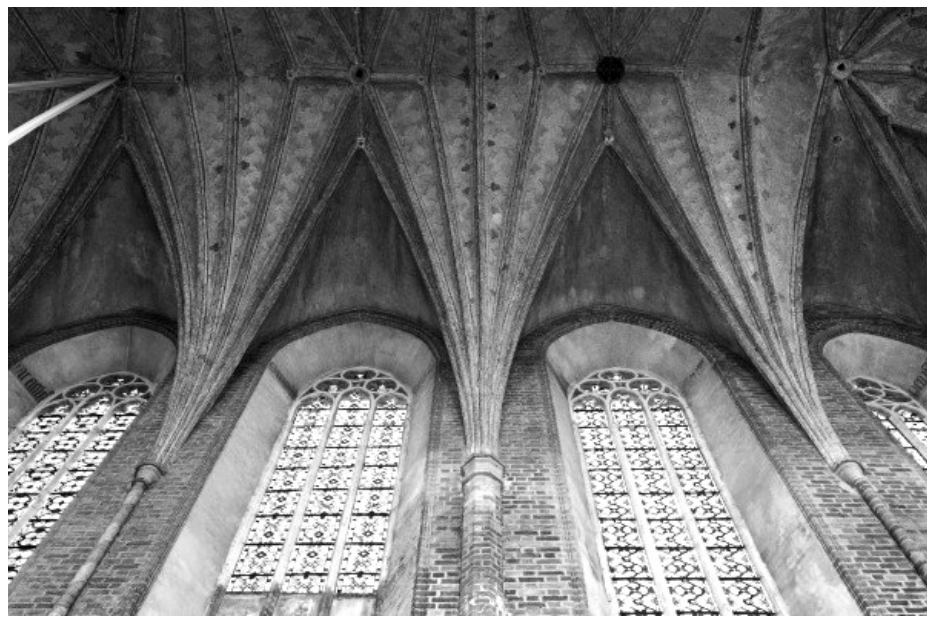

Il. 5 Toruń, kościół św. Jakuba, fragment północnej ściany chóru, fot. A. Skowroński

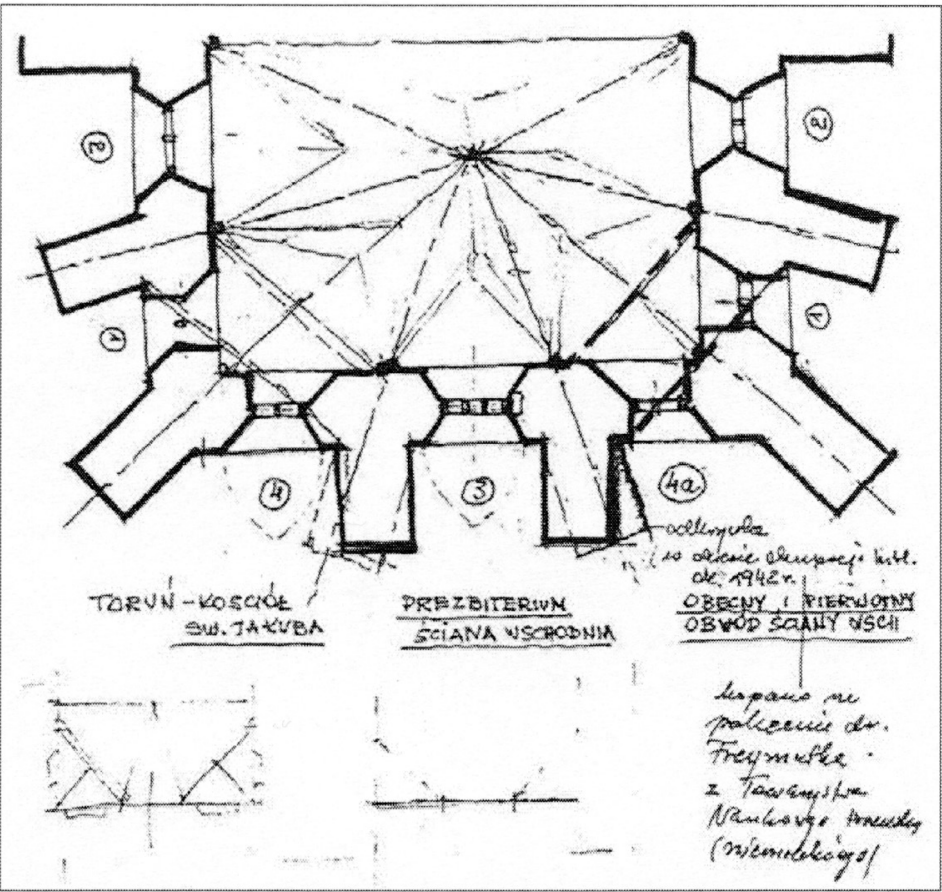

Il. 6 Rysunek I. Sławińskiego z 1942 r. prezentujący ukośny układ wschodnich przypór chóru zaobserwowany w wykopie wykonanym na zlecenie O. Freymutha, wł. E. Gąsiorowski, E. Gasiorowski, Zaginione średniowieczne kościoły Torunia, „Archeologia Historica Polona”, t. 19, Toruń 2011, il. 13, s. 85 


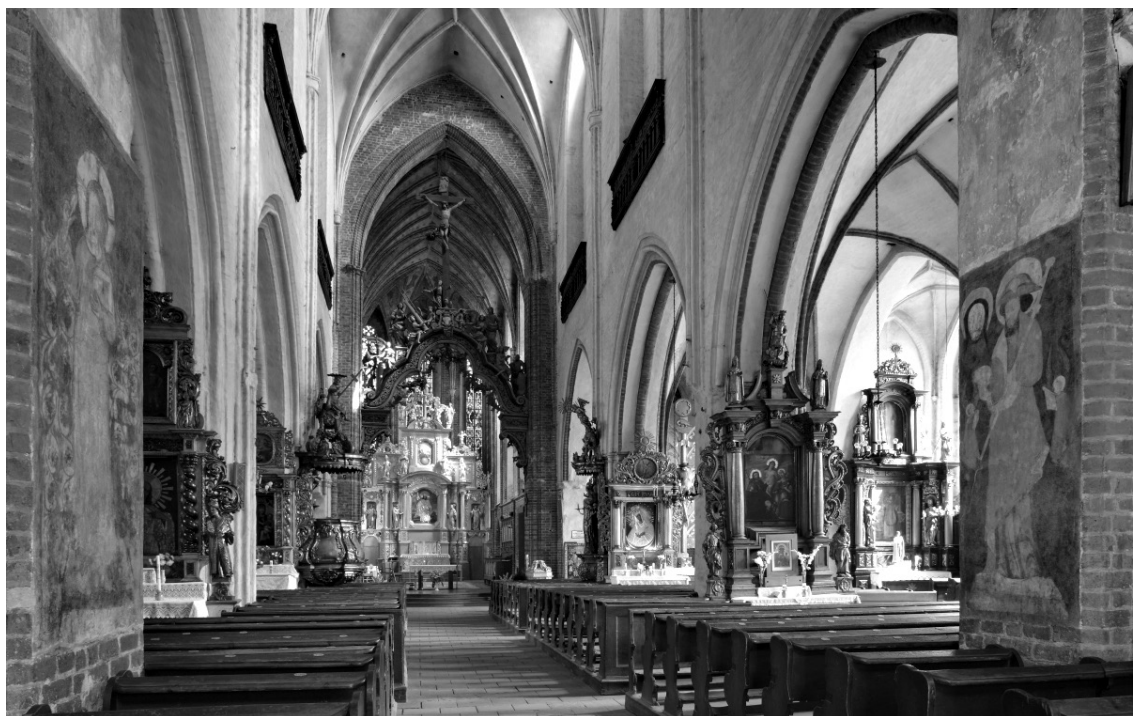

Il. 7 Toruń, kościół św. Jakuba, wnętrze, fot. A. Skowroński

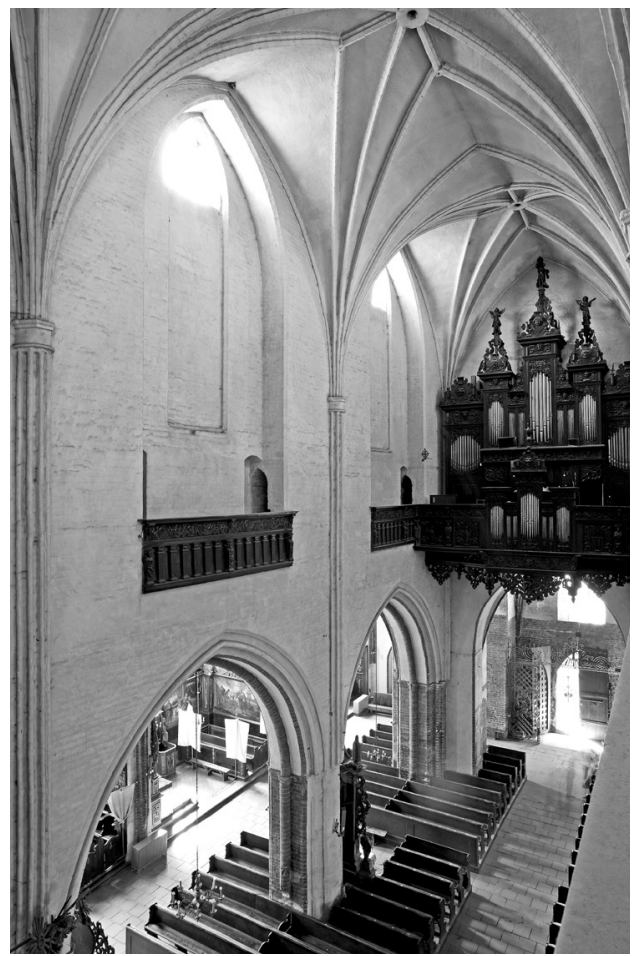

Il. 9 Toruń, korpus kościół św. Jakuba, ściana północna, fot. A. Skowroński 


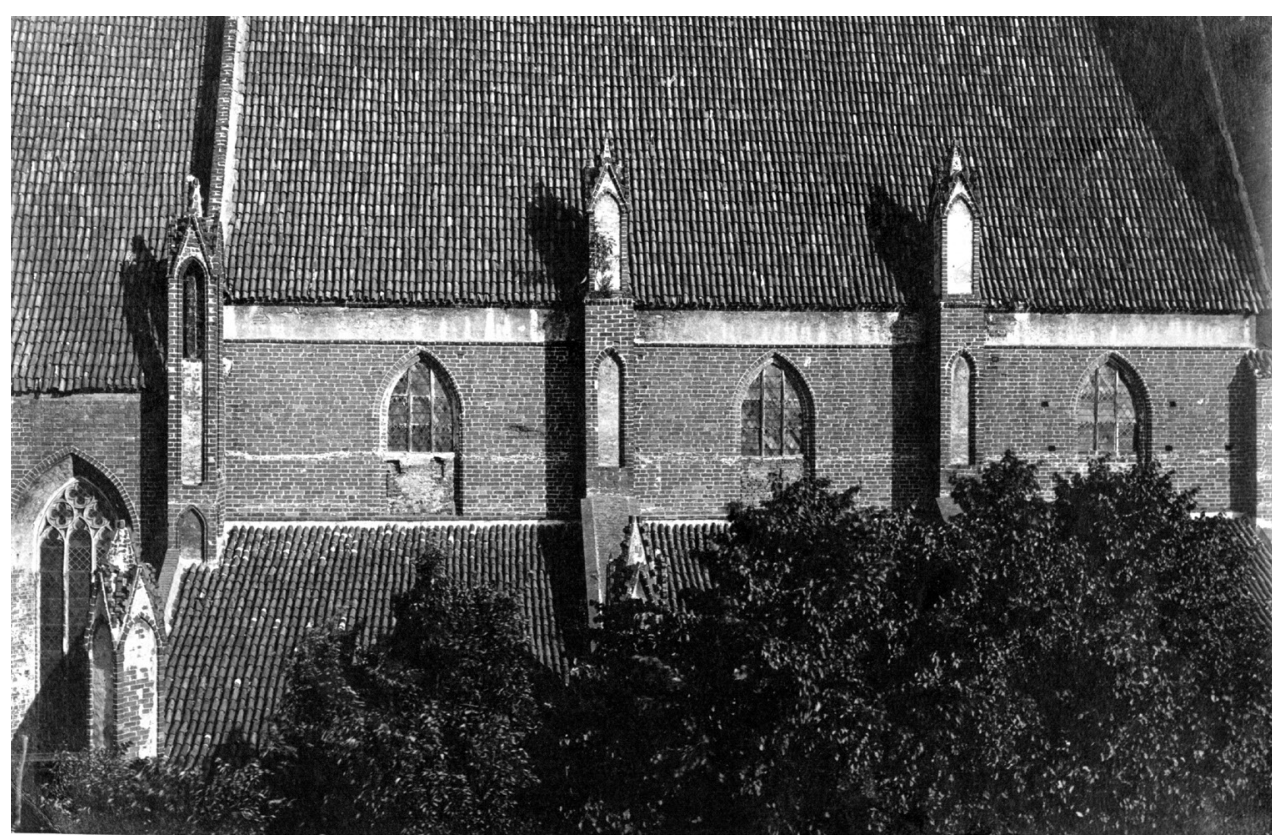

Il. 10 Toruń, elewacja północna korpusu kościoła św. Jakuba, zdjęcie Alexandra Jakobi z 1908 roku, zbiory Książnicy Toruńskiej 